\title{
Earnings Management in Saudi Nonfinancial Listed Companies
}

\author{
Mohammed Al Shetwi \\ Associate Professor of Accounting \\ Community College, Qassim University \\ Buraidah, Saudi Arabia
}

\begin{abstract}
This study investigates the earnings management practices in Saudi nonfinancial listed companies. It examines the effects of IPO events, company size, and leverage on their earnings management activities. The result of the regression model revealed that Saudi nonfinancial listed companies practice earnings management, and the size of a company is negatively related to its level of earnings management. Testing using the independent- sample T-test finds the result to be robust. The finding is in line with the view that larger companies are more capable of monitoring the incentives that may lead management to exercise earnings management than smaller companies. Further, this result implies that a capital market consisting mainly of small and mid-sized companies, such as the Saudi capital market, needs to update financial rules and regulations related to financial reporting.
\end{abstract}

Keywords: earnings management, Saudi nonfinancial listed companies, IPO, company size, leverage

\section{Introduction}

In recent years, earnings management (hereafter, EM), which has an impact on companies' financial reporting quality (FRQ), has received increased attention from practitioners and legislators. EM occurs when managers intentionally alter earnings in order to mislead stakeholders regarding the economic performance of a company or to influence contractual outcomes that depend on financial reporting (Healy and Wahlen, 1999). Previous studies have reported that when the magnitude of EM increases, the quality of earnings decreases, leading to a loss of investors' confidence in the financial reporting system. The literature has documented that EM is driven by factors such an Initial Public Offer (IPO) event, a company's size, and leverage (Gim, Choi, Jang, 2019; Sletten, Ertimur, Sunder, Weber, 2018; Turegun, 2018). The likelihood of EM increases in an environment with a weak rule of law (Beuselinck, Cascino, Deloof, Vanstraelen, 2018; Dyreng, Hanlon, Maydew, 2012). In this regard, Degiannakis, Giannopoulos, Ibrahim, and Rozic (2017) found that countries with a less developed stock market, more concentrated ownership, and lower disclosure level reported a higher level of EM compared to those with a well-developed stock market, more dispersed ownership, and a high level of disclosure. In the case of Saudi Arabia, the government has adopted a new vision for the next decade, known as the 2030 Vision. One of the fundamental objectives of this vision is to increase the contribution of foreign investment in the local economy through the inclusion of non-Saudi investors in the market share. Development of the financial sector is a one of the 2030 Vision programs that aim, among other objectives, to support private sector growth and to ensure the formation of an advanced capital market ${ }^{1}$. However, this ambitious movement is dependent upon how the stock market can be developed in terms of improving the efficiency of governance quality and protecting investors. The question of whether the Saudi stock market is ready to comply with the new vision for the country needs to be answered. In other words, there is a need to investigate levels of FRQ at the inception of the country's new vision policy. The current study is the first study to explore this issue in the period being termed by Saudi legislators as "the after-oil era". Considering that earnings management is an essential factor affecting the quality of financial reporting, the current study aims to investigate the practice of EM in Saudi nonfinancial listed companies. More specifically, this study is an examination of the extent to which EM occurs, and the factors encouraging the occurrence of EM in these companies. The study seeks to determine whether the factors of IPO events, companies' size, and leverage have an impact on the earnings management activities in Saudi nonfinancial listed companies. Using the Ordinary Least Square technique to examine the extent of EM in a sample of 114 Saudi nonfinancial listed companies, the study finds that Saudi nonfinancial listed companies practice EM and that company size is negatively related to the level of EM. This suggests that large companies are less likely to manage earnings due to the efficiency of their control systems.

\footnotetext{
${ }^{1}$ By definition, the 2030 Vision is a bold yet achievable blueprint to guide the nation (i.e. Saudi Arabia) toward a new phase of development covering all aspects of life. In essence, it aims to reduce dependency on oil as a primary source of income in the Kingdom. 
The study makes some contributions both to the literature and to practice. It sheds light on the issue that remains a matter of concern to legislators in Saudi Arabia, in their efforts to introduce new strategies to develop the business environment in Saudi Arabia. In addition, the study provides evidence from a less developed country (Saudi Arabia) supporting the view that larger companies have adequate monitoring systems through which they can ensure effective control procedures and reduce the probability of EM taking place. Since the Saudi capital market consists mostly of small and mid-sized companies ${ }^{2}$, the findings of this study place emphasis on the importance of improving the financial regulations related to small and mid-sized companies, as this approach would contribute to enhancing the efficiency of the capital market in Saudi Arabia.

\section{Literature and Predictions}

\subsection{EM Practices}

EM is an ongoing issue that continues to be addressed in the literature on FRQ. Indeed, definitions of EM in the literature are based on the same dimension: when managers prepare financial reporting, they have the opportunity to intentionally manipulate earnings to gain benefits for themselves. In this context, Healy and Wahlen (1999) defined EM as a method by which managers alter financial reporting by making judgments that could either mislead stakeholders or influence contractual outcomes, both of which depend on accounting information. In fact, EM occurs under two conditions: the first is when managers intentionally seek to mislead users of financial information by abusing the flexibility of accounting methods and alter reported earnings; the second is when managers create information asymmetry by hiding poor performance. In these ways they mislead investors about the value of their equity (Martin, Campbell, Mejia, 2016; Sletten et al., 2018). On the other hand, managers might use insider information to increase their personal gains since they have access to information that is not available to the public (Beneish, 2001). This implies that EM practices entail ethical dilemmas that arise between managers and stockholders. With regard to modelling EM, accrual quality is widely used by researchers to measure the quality of financial reporting (DeFond and Jiambalvo, 1994; Jones, 1991). Accrual models include two independent variables: normal accrual reflects the economic reality of fundamental performance; meanwhile, abnormal accrual is a common indicator used to capture the distortion resulting from choosing the alternative account methods available to management, and thus it is used to measure the magnitude of EM ( Dechow, Ge, and Schrand, 2010).

With regard to the effect of EM on FRQ, studies have revealed that the relation between EM and FRQ is negative, implying that as EM (measured by the volume of abnormal accrual) increases, the accrual quality decreases, leading to poor FRQ (Dechow, Sloan, Sweeny, 1995; DeFond and Jiambalvo, 1994; Jones, 1991). In fact, EM is carried out within the boundaries of the Generally Accepted Accounting Principle (GAAP) and results in distortions of the earnings quality, leading ultimately to poor market efficiency. Thus, efforts should be made to enhance FRQ as a means to improve market efficiency. One way to achieve these objectives is to monitor the level of EM and determine the incentives that encourage EM. Factors contributing to EM remain a matter of debate. However, the research literature has found that the regulatory environments within which companies work have an impact on the level of EM. As noted by Callao, Jarne, and Wroblewski (2014), the country of origin of the sample affects the result of an EM study. This suggests the importance of the results of this present study and why, because it was conducted in Saudi Arabia, one of the less developed countries, it may differ from other studies. To summarise the above discussion, the current study seeks to investigate EM practices in Saudi nonfinancial listed companies and proposes that when the level of abnormal accrual increases, the volume of EM increases leading to lower level of FRQ. Therefore, the first hypothesis of this study is stated as follows: H1: As the level of abnormal accrual increases, the volume of EM increases, leading to lower level of FRQ.

\subsection{EM incentives}

Studies have indicated that the incentives to manage earnings increase when an IPO is imminent (Healy and Wahlen, 1999; Sletten et al., 2018). Prior to the IPO event, managers tend to increase the demand for new shares by exercising earnings management. In this case, investors respond positively to the supply of shares as they are induced by inflated earnings. As a result, companies ensure not only that they sell the maximum number of shares but also that they generate profit as they sell shares at high prices. In particular, shareholders who own companies before the IPO may contribute to the occurrence of EM since they enforce managers to manipulate earnings and affect investors' decision about companies' shares (Sletten et al., 2018).

\footnotetext{
${ }^{2}$ Large companies represent only $26 \%$ of the sample size defined by dummy variable taking 1 if the company size is above the third quartile value (6.64), and zero otherwise.
} 
Unfortunately, prices decrease after the IPO event, so that new investors might not gain as much benefit as they expected. This is because if financial statements are not reliable, they may not be good indicators of future performance. In fact, EM surrounding an IPO is mostly achieved through increasing earnings to maintain a profitable target. Depreciation estimates and bad debt provisions are examples of accounts used by managers to influence earnings surrounding an IPO (Healy and Wahlen, 1999). Several studies have examined the incentives to manage earnings during an IPO event. For example, Teoh, Wong, and Rao (1998) examined whether companies engage in EM by reporting high IPO accrual. They proposed that companies that have plans to sell their shares in the market tend to adopt more income-increasing depreciation policies in order to boost earnings before an IPO. The results revealed that companies report increased earnings during an IPO event, while the post-IPO performance is below the pre-IPO performance, implying that companies managed their earnings opportunistically so as to mislead investors during the IPO event.

The study by Sletten et al., (2018) was conducted to answer the question: When and why do IPO companies manage the earnings? The researchers used a sample of 2648 IPO companies over the 1990-2013 period. They examined both the pre-IPO period and the pre-lockup expiration date to identify the timing and the motive behind EM. By using the modified Jones model to measure abnormal accrual, they found no evidence of income-increasing EM prior to the IPO. Looking to the Saudi case, it is expected that in the near future there will be an increasing number of IPOs due to the recent strategies of the government to open the market to local and foreign investment. This implies that examining the incentives to manage earnings during the IPO event in Saudi capital market would be of more concern. Based on the above discussion, the second hypothesis of this study is stated as follows: H2: IPO companies report aggressive abnormal accrual during the IPO event. Leverage is the second factor that might drive management to exercise EM. Previous studies have reported that leverage has an important impact on the occurrence of EM (DeFond and Jiambalvo, 1994; Turegun, 2018). Typically, financial statements provide information that enables lenders to evaluate the companies' ability to pay the principle payment and interest. In the case of highly leveraged companies, EM occurs when managers intentionally distort earnings to avoid violating debt covenants (DeFond and Jiambalvo, 1994). Further, in order to attract low cost loans, managers tend to increase earnings to obtain lenders' confidence and boost their bargaining position when negotiating a debt contract.

In this context, DeFond and Jiambalvo (1994) examined the presence of EM as a result of debt covenant restrictions in the year preceding the year of violation. Their findings provide evidence of positive abnormal accrual, implying that debt covenant restriction does influence accounting choices in the year before the violation. However, Gim et al., (2019) reported that not all leveraged companies have the same pattern (i.e. income-increasing EM). According to another point of view, the control view, companies experiencing a high level of leverage are under the risk of violating their debt covenant; therefore, the boards of those companies impose extra control procedures to ensure that debt transactions are carried out according to accounting policies (Gim et al., 2019). Thus, the adequate control system of leveraged companies helps in reducing the opportunity to exercise EM, indicating that the relationship between leverage and EM in these cases is negative. In a recent study, Turegun (2018) examined the effect on borrowing cost, among other factors, on the level of EM in Turkish companies. The findings of this study revealed that companies with a high level of leverage have a lower level of EM, which supports the control hypothesis that monitoring and governance in highly leveraged companies are effective in reducing EM activities.

In similar vein, Gim et al. (2019) examined the effect of leverage on EM across franchise companies. They proposed that managements in franchise companies are less induced by the motive to engage in EM. The results supported the hypothesis and revealed that the impact of financial leverage on EM is weaker for franchise companies. This result provides additional evidence supporting the control view. Summarizing, there are two opposing views regarding the relation between leverage and EM. In first view, it is proposed that leverage is positively related to EM implying that as leverage increases, the volume of EM increases. Advocates of this view argue that managers engage in EM to avoid violating debt covenants. Meanwhile, the other view proposes that opportunistic behavior of managers is restricted by the implementation of an effective control system in highly leveraged companies. In this case, the relationship between leverage and EM is negative, indicating that as leverage increases, the effectiveness of control system increases leading to a reduced level of EM. However, the majority of companies listed on TADAWL (i.e. the Saudi capital market) ${ }^{3}$ are small and mid-sized companies. Considering the low cost of debt in the Saudi market, small and mid-sized companies would prefer to finance their activities through borrowing from banks and financial institutions. It is expected in such a situation that leverage would be an important factor affecting EM in Saudi nonfinancial listed companies.

\footnotetext{
${ }^{3}$ Large companies represent only $26 \%$ of the sample size defined by dummy variable taking 1 if the company size is above the third quartile value (6.64), and zero otherwise. 
As previous studies have provided contradictory results on the relation between leverage and EM, this study does not assume the direction of the relationship between leverage and EM. Hence, the third hypothesis of this study is stated as follows:

H3: There is a relationship between leverage and EM in Saudi nonfinancial listed companies.

Company size has an important impact on the extent to which EM occurs (Nalarreason, Sutrisno, Mardiati, 2019; Pradipta and Susanto, 2019; Turegun, 2018). Large companies, for example, have multiple sectors which they can use to cover losses or to hide gains. In this regard, Dyreng et al., (2012) stated that companies with foreign operations engage more in EM by using their subsidiaries that operate in remote sites. This indicates that large companies have an ability to exercise EM as they have multiple alternatives for carrying out EM compared to smaller companies. Moreover, it is noted that the nature of large companies' operations is more complex to the extent that it is difficult to monitor them all closely, so that would in turn increase the opportunity to manage earnings (Gim et al., 2019). In fact, some large companies use their funds to finance activities assigned for implementing long-term plans rather than for monitoring activities; thus, they have weaker control system and in turn lower FRQ. In this regard, Turegun (2018) found that large companies are more likely to engage in EM practices. Similarly, in their study, Nalarreason et al. (2019) found that the size of company has a positive impact on EM, indicating that when company size increase, the managements are more induced to engage in EM and they concluded that the relationship between company size and EM is positive.

Conversely, some studies have argued that the larger the company, the lower the likelihood of EM activities. As Gim et al., (2019) contended, large companies are more capable of maintaining an adequate monitoring system that helps in detecting and preventing EM. In fact, large companies can engage Big 4 auditors, buy advanced control systems, contract with outside board members having multiple directorships, and provide internal control with adequate resources. In these ways they improve their monitoring system and reduce the motivation for EM. According to the high competition model, large companies are more sensitive to the market response to financial scandal, so they are more likely to maintain transparency and accountability of financial reporting. In this context, Pradipta and Susan to (2019) suggested that large companies are committed to retaining their investors and typically do not engage in EM activities such as income smoothing. They examined how company size affects income smoothing as a one dimension of EM. They found that the size of company is negatively related to a level of income smoothing, implying that as the company' size increases, the level of income smoothing(i.e. EM) decreases and, in turn, the quality of accounting earnings increases. In sum, this view suggests that the relation between company size and EM is negative: in other words, as company' size increases, the volume of EM decreases. Summarizing, there are two conflicting assumptions regarding the impact of company size and EM. Some studies have argued that as company size increases, the complexity of operations increases leading to less monitoring on financial reporting and therefore, more opportunity for EM. On the other hand, other studies have argued that large companies are more capable of maintaining an adequate monitoring system by which they can reduce the incentives to manage earnings. Based on above discussion, the present study proposes that there is a relationship between EM and the size of Saudi nonfinancial listed companies, but no direction is assumed. Hence, the fourth hypothesis of this study is stated as follows: H4: Company size is related to EM practices in Saudi nonfinancial listed companies

\section{Research Design}

\subsection{Model}

As explained above, the current study examines EM practices and some factors affecting EM in Saudi nonfinancial listed companies, namely IPO event, leverage, company size. To test the study's hypotheses, the following model is developed: $\mathrm{AACC}=f(\mathrm{IPO}, \mathrm{LEV}, \mathrm{SIZE}, \mathrm{CONTROL}, \mathrm{e})$

The dependent variable of this study is EM. In line with previous studies (DeFond and Jiambalvo, 1994; Jones, 1991) EM is examined by abnormal accrual (AACC) and it is proposed that as abnormal accrual increases, the level of EM increases. However, the Modified Jones model adopted by DeFond and Jiambalvo (1994) is used to measure the magnitude of abnormal accrual as employed through the following equation: TAC ijt = NACC ijt+ AACC ijt

TAC ijt is a total accrual for company $i$ in industry $j$ and year $t$, and is broken down into two categories, Normal Accrual (NACC) and Abnormal Accrual (AACC). Normal accrual is estimated from the following regression model: NACC $i j t=\widehat{\alpha}_{j}[1 / A i j t-1]+\widehat{\beta}_{1 \mathrm{j}}[\Delta R E V i j \mathrm{t}-\triangle R E C i \mathrm{jt} / A i \mathrm{jt}-1]+\widehat{\beta}_{2 \mathrm{j}}[P P E i \mathrm{jt} / A i j \mathrm{jt}-1]$

$\widehat{\alpha}, \widehat{\beta}_{1}, \widehat{\beta}_{2}$ are derived from the following equation:

$$
T A C \text { ijt } / A \text { ijt }-1=\alpha_{\mathrm{j}}[1 / A i j t-1]+\beta_{1 \mathrm{j}}[\Delta R E V i j \mathrm{t} / \text { Aijt }-1]+\beta_{2 \mathrm{j}}[\text { PPEijt } / \text { Aijt }-1]+\varepsilon i j t
$$


After calculating TAC and NACC, the AACC is computed by deducting NACC from TAC as shown in the following equation ${ }^{4}$ :

AACCijt $=$ TACijt - NACCijt

The independent variables: The study includes three independent variables as follows: First, IPO is defined as whether company has issued equity in a given year. It is measured using a dummy variable, taking 1 if the company has issued equity greater than $5 \%$ of its total assets ${ }^{5}$ in the year beginning2015, and zero otherwise (Beuselinck et al., 2018); Second, Leverage (LEV), it is calculated by dividing the total liabilities by the total asset (Beuselinck et al., 2018; Teoh, et al., 1998; Turegun, 2018); Third, Company Size (SIZE) is measured by the natural log of total assets (Beuselinck et al., 2018, Gim et al., 2019).

Control Variables: drawing upon prior studies on EM, several control variables are included in the regression model. Return on Asset (ROA) is included to capture the impact of profitability on EM. Prior studies provided evidence that companies with a high level of return on asset might be more likely to engage in EM in order to maintain profitability (Ferramosca and Allegrini, 2018; Gim et al., 2019; Sletten et al., 2018); Extreme ROA (EXROA) is used to alleviate the concern that the modified Jones model might provide biased estimates of abnormal accrual in the case of companies experiencing extreme return on asset (Dechow, et al., 1995); Age (AGE) is adopted to capture the effect of company age on EM as suggested by prior studies (Dyreng et al., 2012; Ferramosca and Allegrini, 2018). Audit Quality (BIG 4) is included to control for the effect of audit quality on EM. It is proposed that companies that use Big 4 auditors are less likely to engage in EM since Big 4 are known to provide soundaudit work (Gim et al., 2019); the variable Sale Growth (GROWTH) controls for the relationship between growth and EM. Prior studies suggested that companies with higher growth are more likely to exhibit a higher level of EM (Beuselinck et al., 2018; Gim et al., 2019). All variables are defined as presented in Table 1.

\subsection{Sample Size}

The initial sample included all Saudi nonfinancial listed companies in 2015. The reason for selecting the year of 2015 was to examine the EM practices in the Saudi capital market before it became the focus of foreign investment attention $^{6}$. A total of 128 companies were listed in 2015; three companies were delisted in 2015; five companies were deleted due to incomplete data, while five companies failed to comply with DeFond and Jiambalvo's (1994) rule that requires a minimum of six companies in each industry in order to run the regression model. One company was deleted due to case-wise diagnosis. The final sample consisted of 114 companies. This sample size is sufficient to calculate abnormal accrual as it compares well with sample sizes used in prior studies. Callao et al., (2014) provided examples of some studies whose findings were based on small sample sizes: Byard, Hossain, Mitra(2007) used 29 listed companies, Jones (1991) used only 31 companies, while the Key study (1997) used 47 companies. Information on study variables was collected from the annual financial reports presented in the TADAWL web site. Both TADAWL and the Global Industry Classification Standard (GICS) were used to analyse the sample into 8 industrial categories, which were: Petrochemical (14), Cement (13), Agriculture (14), Multi-investment (6), Multi- industry (20), Building \& Construction (16), Real-estate (9), Retail (22).

\section{Results}

\subsection{Descriptive Analysis}

The information in Table 2 shows the descriptive statistics for the research variables. For the sample observation, the abnormal accrual ranged from -.27 to .21 with a mean value of .07 . The retail sector achieved the highest value of income-decreasing EM (-.27), followed by Building \& Construction (-.16), while the Multi-industry achieved the highest value of income-increasing EM (.21) followed by Cement (.14) and multi-investment (.13). The mean value of company size is 6.43 , while the mean value of leverage is .40, indicating that Saudi nonfinancial listed companies are moderately leveraged financially. Regarding IPO, on average $6 \%$ of the sample companies were IPO companies. A lower percentage of IPO emphasized the importance of implementing a plan to improve the investment climate in Saudi Arabia. With regard to control variables, the mean value of ROA was .07 indicating that Saudi nonfinancial listed companies experienced lower earnings in 2015. On average, 57\% of the sample companies used a Big 4 auditors, reflecting a moderate interest given to audit quality and in turn to FRQ on the part of Saudi nonfinancial listed companies.

\footnotetext{
4 Each variable is scaled by the total asset

${ }^{5}$ According to listing rule, at least $30 \%$ from the shares, issued should be available to the public. Thus, this condition has already been met when taking the $5 \%$ threshold.

${ }^{6}$ After activatingthe 2030 Vision in an official form. 
Meanwhile, the median age of companies in the sample was 16 years, and the mean annual percentage change in sale (i.e. sale growth) was - .97 indicating that most companies experienced drop in their sales in the second period of 2015.

\subsection{Regression Result}

Un-tabulated results of Pearson correlation analysis revealed that none of explanatory variables are strongly related to each other; the tolerance value is greater than .10, while VIF is below 10 for all variables. indicating an absence of multicollinearity (Hair, Anderson, Black, Babin, Tatham,2006). Table 3 reports the result of the regression model. The $\mathrm{R}$ square of the model is $13 \%$; this indicates that the overall model explained about 13 percent of the variance in the dependent variable (i.e. abnormal accrual). A relatively low percentage of $\mathrm{R}$ square is common in the research studies that have explored the EM phenomenon, as noted by Ferramosca and Allegrini (2018). However, analysis yielded a significant model with $\mathrm{F}$ value of 2.03, significant at the .05 level. The result shows that company size (SIZE) is significantly negatively related to abnormal accrual $(\mathrm{p}=.057)$, suggesting that in this sample, as company size increases, the level of EM decreases. In other words, the larger companies are less likely to engage in EM than the smaller companies. The result is consistent with the argument that large companies are more capable of having an effective control system by which they maintain transparency and accountability of financial reporting and reduce the incentives for EM activities (Gim et al., 2019). This result is in agreement with those reported in previous studies (Dyreng et al., 2012; Pradipta and Susanto, 2019). Further, the result implies that the capital market consisting mostly of small and mid-sized companies ${ }^{7}$ needs to update the financial rules and regulations related to financial reporting. In the case of Saudi, this issue should be addressed with more concern in light of the recent changes in the economic environment and the developmental business structure of Saudi listed companies.

Contrary to expectations, the result suggests that an IPO event does not affect the level of EM ( $\mathrm{P}=.128)$. Thus, the second hypothesis of this study is not supported. The reason for this result might be attributed to the view that IPO events are accompanied by intense security imposed by control bodies inside and outside the company concerned (Sletten et al., 2018), which restrict any opportunity to manage earnings since such an activity would be detected easily by the control system. However, this issue might become more of a concern in the future as the plans to attract investment become realized. Similarly, the results also suggest that leverage is not significantly associated with the extent of EM $(\mathrm{P}=.175)$. Thus, the third hypothesis of this study is not supported. One explanation for this result is that violating a debt agreement might not be a threat to the companies, considering that the efficiency of their operation would provide sources for refunding ${ }^{8}$. On the other hand, the highly leveraged cases call for more scrutiny and control over the actions undertaken by management, including those relating to financial reporting. Regarding the results of control variables, the findings reveal that extreme ROA and company's age are positively significantly related to EM, implying that the occurrence of EM increases when companies have extreme values of ROA and when a company's age increases.

\subsection{Sensitivity Analysis}

To ensure the stability of the initial result, the study used the independent- sample T- test to check whether the mean value of abnormal accrual for large companies is higher than those for small companies. As presented in Table 4, the result shows that the mean difference is significant at the .05 level $(\mathrm{P}=.02)$. A further look into this difference in the value of abnormal accrual reveals that the magnitude of the difference between large and small companies in terms of abnormal accrual is relatively large. being higher than the "moderate" level suggested by Cohen (1988) (Eta Square = $.09)^{9}$.

\section{Conclusion}

EM continues to remain an issue that receives significant attention from researchers. Prior studies suggested that EM reduces the reliability and relevance of financial reporting and, in turn the efficiency of a capital market (DeFond and Jiambalvo, 1994; Jones, 1991). For this reason, attention has been focused on finding a solution to deal with EM concern in order to improve the investment environment. The current study aims to address this issue and to investigate EM practices and incentives to manage earnings in Saudi nonfinancial listed companies. Using a sample of 114 nonfinancial Saudi companies listed in 2015, this study finds that Saudi nonfinancial listed companies do practice EM, although large companies have less incentives to engage in EM. It is suggested that this may be because they possess more effective control systems and hence are more capable of detecting and preventing such practices.

\footnotetext{
${ }^{7}$ Large companies represent only $26 \%$ of the sample size defined by dummy variable taking 1 if the company size is above the third quartile value (6.64), and zero otherwise.

${ }^{8}$ Companies can easily waive the breach of debt covenants that, in some cases, exceeded approximately totaling 3.23 billion, as in the case of Mobily, the second biggest Saudi telecommunication company, according to a TADAWL announcement.

${ }^{9}$ According to Cohen (1988), the effect size is small if $\mathrm{Eta}^{2}=.01$; moderate if $\mathrm{Eta}^{2}=.06$; large if $\mathrm{Eta}^{2}=.14$.
} 
Furthermore, the current study finds that highly leveraged companies and IPO companies do not perform EM. This can be explained from the perspective of the control view, which proposes that effective control procedures imposed on companies during these specific circumstances helps to reduce opportunities for EM.

In addition, the findings also reveal that companies experiencing performance extremes are more likely to engage in EM; while longer established companies (measured by the time from their date of listing) show an increase in EM practices. This study makes some contributions to both theory and practice. The results provide some evidence from a less developed country, Saudi Arabia, that support the view that company's size is an important factor affecting the EM phenomenon. The fact that small and mid-sized companies have more incentives and opportunities to engage in earnings management, calls for an improvement in regulations to enhance the control procedures on such companies. Moreover, since small and mid-sized companies represent the majority of nonfinancial companies listed on TADAWL (the Saudi capital market), Saudi legislators should pay more attention to this issue if they want to build successful strategy to improve the capital market. However, the current study has some limitations. While ideally the pre-IPO data should be used to measure abnormal accrual, this study focuses on data at the time of the IPO event. However, the same approach has been used in previous studies such as Teoh et al. (1998) and is not considered to be a serious drawback as the literature indicates that companies continue to practice EM in the IPO year to prevent the pre-IPO EM from becoming apparent too quickly (Sletten et al., 2018).

Sample size could be considered another limitation. While the current study sample included all Saudi nonfinancial listed companies in the year of 2015, the number of listed companies may be small when compared to studies conducted in the US and European countries. However, as mentioned earlier, a number of other studies carried out in the area of EM are even smaller; for example, Jones (1991), Byard et al. (2007), and Key (1997).

\section{References}

Beneish, D. (2001). Earnings management: A Perspective, Managerial Finance, 27 (12), 3-17.

Beuselinck, C., Cascino, S., Deloof, M., Vanstraelen, A. (2019). Earnings Management within Multinational Corporations. The Accounting Review, 94 (4), 45-76.

Byard D., Hossain M. and Mitra S. (2007). US oil companies' earnings management in response to hurricanes Katrina and Rita, Journal of Accounting and Public Policy, 26, 733-748.

Callao, S., Jarne, J.I., Wróblewski, D. (2014). The development of earnings management research A review of literature from three different perspectives. Theoretical Journal of Accounting, 79 (135), 135-177.

Cohen, J. (1988). Statistical power analysis for the behavioral sciences (2nd ed.). Hillsdale, NJ: Lawrence Earlbaum Associates.

Dechow, P. M., Ge, W.,Schrand, C. (2010). Understanding earnings quality: A review of the proxies, their determinants and their consequences. Journal of Accounting and Economics ,50 (2-3), 344-401.

Dechow, P. M., Sloan, R. G., Sweeney, A. P. (1995). Detecting earnings management. The Accounting Review, 70, 193-225.

DeFond, M. L., Jiambalvo, J. (1994). Debt covenant violation and manipulation of accruals. Journal of Accounting and Economics, 17, 145-176.

Degiannakis, S., Giannopoulos, G., Ibrahim, S., Rozic, I. (2019). Earnings management to avoid losses and earnings declines in Croatia. International Journal of Computational Economics and Econometrics, 9 (3), 219-238.

Dyreng, S. D., Hanlon, M., Maydew, E. L. (2012). Where do firms manage earnings. Review of Accounting Studies, $17,649-687$.

Ferramosca, S., Allegrini, M. (2018). The complex role of family involvement in earnings management, Journal of Family Business Strategy, 9 (2), 128-141.

Gim, J., Choi, K., Jang. S. (2019). Do franchise firms manage their earnings more? Investigating the earnings management of restaurant firms. International Journal of Hospitality Management, 79, 70-77.

Hair, J. F., Anderson, R. E., Tatham, R. L., Black, W. C., \&Babin, B. J. (2006). Multivariate Data Analysis: (sixth edition), Prentice-Hall International, London.

Healy, P. M., \&Wahlen, J. M. (1999). A review of earnings management and its implications for standard setting. Accounting Horizons, 13(4), 365-383.

Jones, J. (1991). Earnings management during import relief investigations. Journal of Accounting Research, 29, 193228.

Key, K. (1997). Political cost incentives for earnings management in the cable television industry. Journal of Accounting and Economics, 23, 309-337. 
Martin, G., Campbell, J. T., Gomez-Mejia, L. (2016). Family Control, Socioemotional Wealth and Earnings Management in Publicly Traded Firms. The Journal of Business Ethic, 133 (3), 453-469.

Nalarreason,K. M., Sutrisno T, Mardiati, E. (2019). Impact of Leverage and Firm Size on Earnings Management in Indonesia.International Journal of Multicultural and Multireligious Understanding, 6 (2), 8-19.

Pradipta, A., Susanto, Y. K. (2019). Firm Value, Firm Size and Income Smoothing. Journal of Finance and Banking Review, 4 (1) 01-07.

Sletten, E., Ertimur, Y., Sunder, J. Weber, J. (2018). When and why do IPO firms manage earnings?Review of Accounting Studies, 23, 872-906

Teoh, S., Wong, T. J., \& Rao, G. (1998). Are accruals during initial public offering opportunistic? Review of Accounting Studies, 3, 175-208.

Turegun, N. (2018). Effects of borrowing costs, firm size, and characteristics of board of directors on earning management types: a study at Borsa Istanbul. Asia-Pacific Journal of Accounting \& Economics, 25(1-2) 4256.

\section{Appendix}

\begin{tabular}{|c|c|c|c|c|c|c|}
\hline \multicolumn{7}{|c|}{ 7.1: Variables Definition } \\
\hline AACC & $=$ & \multicolumn{5}{|c|}{ The absolute value of discretionary accruals } \\
\hline IPO & $=$ & \multicolumn{5}{|c|}{$\begin{array}{l}\text { A dummy variable, taking } 1 \text { if the company has issued equity greater than } 5 \% \\
\text { of its total assets in the year beginning } 2015 \text {, and zero otherwise. }\end{array}$} \\
\hline LEV & $=$ & \multicolumn{5}{|c|}{ The ratio of total liabilities to total assets } \\
\hline SIZE & $=$ & \multicolumn{5}{|c|}{ The natural log of total assets } \\
\hline ROA & $=$ & \multicolumn{5}{|c|}{ The return on asset, measured by dividing net income before tax on total asset. } \\
\hline EXROA & $=$ & \multicolumn{5}{|c|}{$\begin{array}{l}\text { Extreme performance, measured by a dummy variable, taking } 1 \text { if company is } \\
\text { within the outliers of } \pm 10 \% \text { of the sample for performance (ROA) and " } 0 \text { " } \\
\text { otherwise. }\end{array}$} \\
\hline AGE & $=$ & \multicolumn{5}{|c|}{ The number of years from the first listing in TADAWL. } \\
\hline BIG4 & $=$ & \multicolumn{5}{|c|}{$\begin{array}{l}\text { The audit process quality, measured by " } 1 \text { " if company belongs to Big4,"0" } \\
\text { =otherwise }\end{array}$} \\
\hline GROWTH & $=$ & \multicolumn{5}{|c|}{ Annual percentage change in sales } \\
\hline \multicolumn{7}{|c|}{ 72. Descriptive Statistics } \\
\hline Variable & \multicolumn{2}{|c|}{ Minimum } & Maximum & Mean & Median & Standard deviation \\
\hline AACC & \multicolumn{2}{|c|}{-27} & .21 & .07 & 0612 & 056 \\
\hline IPO & \multicolumn{2}{|l|}{0} & 1 & .06 & .00 & .241 \\
\hline LEV & \multicolumn{2}{|l|}{.02} & .84 & .40 & .39 & 209 \\
\hline SIZE & \multicolumn{2}{|l|}{4.97} & 8.52 & 6.43 & 6.38 & .644 \\
\hline ROA & \multicolumn{2}{|l|}{-.18} & .36 & .07 & .063 & .088 \\
\hline EXROA & \multicolumn{2}{|l|}{0} & 1 & .09 & .00 & .284 \\
\hline AGE & \multicolumn{2}{|l|}{0} & 45 & 15.99 & 16 & 13.03 \\
\hline BIG4 & \multicolumn{2}{|c|}{0} & 1 & .57 & 1 & .497 \\
\hline GROWTH & \multicolumn{2}{|c|}{-2.57} & 1.33 & -.97 & -.90 & .611 \\
\hline
\end{tabular}




\begin{tabular}{|c|c|c|c|c|c|}
\hline \multicolumn{6}{|c|}{ 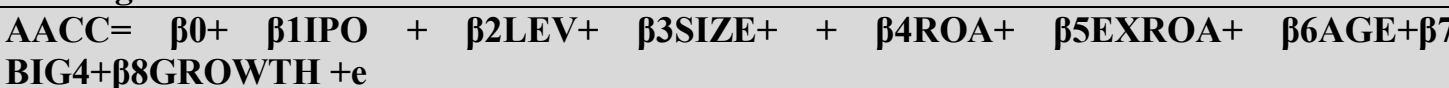 } \\
\hline Variables & Exp sign & $B$ & VIF & t-value & $p$-value * $^{*}$ \\
\hline Intercept & &. .147 & & 2.63 & .01 \\
\hline IPO & + & .035 & 1.20 & 1.54 & .128 \\
\hline LEV & $+/-$ & .04 & 1.62 & 1.36 & .175 \\
\hline SIZE & $+/-$ & -.018 & 1.37 & -1.92 & $.057 *$ \\
\hline ROA & + & -.053 & 1.36 & -.79 & .429 \\
\hline EXROA & + & .034 & 1.09 & 1.822 & $.071^{*}$ \\
\hline AGE & $?$ & .001 & 1.24 & 1.915 & $.058^{*}$ \\
\hline BIG4 & - & .005 & 1.27 & .414 & .680 \\
\hline GROWTH & + & -.003 & 1.02 & -.343 & .732 \\
\hline
\end{tabular}

* $p$-values represent one-tailed tests when direction of coefficient is consistent with expectations.

$R^{2}=13$

$F$-ratio $=2.03$

Sig. $F<0.05$

Variables are as defined in model specification in methodology section.

\section{4: Independent Samples Test}

\begin{tabular}{|c|c|c|c|c|c|c|c|c|c|}
\hline & \multicolumn{2}{|c|}{$\begin{array}{lll}\text { Levene's } & \text { Test } & \mathrm{f} \\
\text { Equality } & & \\
\text { Variances } & & \\
\end{array}$} & \multicolumn{7}{|c|}{ t-test for Equality of Means } \\
\hline & & & & & Sig. & -Mean & Std. E & \begin{tabular}{l|l}
$90 \%$ \\
Interval \\
Error Difference
\end{tabular} & $\begin{array}{l}\text { Confidence } \\
\text { of the }\end{array}$ \\
\hline & $\mathrm{F}$ & Sig. & $t$ & df & tailed) & Difference & Difference & e $\quad$ Lower & Upper \\
\hline $\begin{array}{l}\text { DACEqual variances } \\
\text { assumed }\end{array}$ & 1.494 & 227 & 2.396 & 56 & .020 & -.03840 & .01603 & -.06521 & -.01160 \\
\hline $\begin{array}{l}\text { Equal variances } \\
\text { not assumed }\end{array}$ & & & 2.366 & 47.5 & 0.022 & -.03840 & .01623 & -.06563 & -.01118 \\
\hline
\end{tabular}

